\title{
The Formation and Development of the Scientific School of Mechanical Engineering and Materials Science of Professor V. O. Dobrovolsky at Odessa Polytechnic Institute in the 1930s-1960s
}

Scientific progress in the field of mechanical engineering and the development of higher education institutions that shape the face of the intellectual potential of a country are directly related to the activities of scientific schools that produce and develop specific areas of knowledge, multiply the scientific and pedagogical potential of the country, preserve traditions and approaches and create a link of heritage between scientific generations. Scientists-leaders, founders who shape scientific change with a particular worldview and promote creative and innovative activity are not only representative of their pedagogical level but also demonstrate the viability and importance of their ideas for science in the long run. One of Ukrainian figures who made a fundamental contribution to the development of science was Viktor Opanasovich Dobrovolsky (1884-1963), who founded his scientific school on issues of mechanical engineering and materials science at Odessa Polytechnic Institute (hereafter referred to as OPI).

Viktor Opanasovich Dobrovolsky was one of the most prominent scientists of OPI. Doctor of technical sciences, a professor, distinguished researcher, the author of numerous scientific publications and a man who stood at the origins of OPI, he left a prominent mark in the history of science, not only as a scientist but also as a teacher who discovered and facilitated the formation of a number of young researchers.

Dobrovolsky's scientific school and its achievements are represented by the activities of three generations of students, who have worked and continue to work at OPI and other educational establishments of Ukraine, making scientific discoveries and training young people for industry and science. Previously, the school has not been the subject of complex scientific research and thus a detailed study and analysis is required for an overview of the comprehensive history of Ukrainian engineering.

Born in Trostyanets, Kharkiv Province (now Sumy region), Dobrovolsky graduated from the Mechanical and Technological Faculty of Kharkov Institute of Technology in 1908. In 1917, he participated in the establishment of OPI. During his work at the Institute, the scientist became a professor in 1935, doctor 
of technical sciences in 1936 (Archive of ONPU, F. R-126/11.250, fol. 12). He held the position of head of the Department of Machine Parts from 1923 to 1963. The scientist worked on solving various problems of mechanical engineering and materials science, features of resistance of materials, calculation of machine parts, which were set out in 160 scientific and pedagogical publications, including monographs Needle Bearings, Multi-Bucket Dry Excavators, Multi-Bucket, Modern Steam Cars and Tractors, Belt Transmission, Basic Principles of Designing of Modern Machines and textbooks, such as Machine Parts (translated into English, French, Spanish, Arabic and Chinese), and others.

The history of Dobrovolsky's scientific school dates back to 1934 when the Department of Machine Parts was granted the right to open a postgraduate course. In 1934-1963, the scientist set up his scientific school at OPI, where he prepared 37 candidates of technical sciences. In addition to the pedagogical and organizational activity of the students of the first generation of the scientific school, Dobrovolsky contributed to the emergence of the second and third scientific generations, and the transformation of the scientific school into a multilevel one.

Dobrovolsky's scientific school was characterized by his ability to deeply understand the essence of research, to identify systemic scientific questions and to provide substantiated practical answers to them. The relevance of the results obtained, their mandatory experimental confirmation, have become not only the defining features of the creativity of the scientist but also of his students and followers.

The directions of the scientific research carried out by Professor Dobrovolsky and the students of his scientific school were versatile and varied in topics and covered a wide range of contemporary scientific problems, which can be further divided into studies on materials science and material resistance, improvement of calculation norms, machine and machine parts.

Lazar Borisovich Ehrlich (1906-1977), one of Dobrovolsky's first students and a graduate of the evening working Industrial Institute (Archive of ONPU, F. R-126/24/324.89, fol. 1), was involved in the development and design of machine tools for machine building and research of their drives. In 1939, under Dobrovolsky's lead, he defended his dissertation on the topic of Questions of Rational Machine Design, in which he studied the stages of designing machines, problems of calculation and the design of different types of machines. 
Ehrlich's scientific work in the field of machine tool design was outlined in his monograph Rationalization of Calculations in Machine Design (1971). His scientific works, like those of his teacher, are distinguished by their volume and variety and include more than 100 scientific publications and inventions on various issues of mechanical engineering.

Working at OPI, Ehrlich was involved in the training of the young personnel for a long time, developing a line of research laid out by Dobrovolsky on the details of machines and mechanisms. Under his supervision, doctoral theses were defended by T. B. Dashevsky (1941), V. A. Kosobudsky (1970), and V. F. Semeniuk (1970), doctor of technical sciences, Honored Worker of Science and Technology of Ukraine, president of the Lifting and Transport Academy of Sciences of Ukraine. Semeniuk has authored 287 scientific works, including 3 monographs, 98 copyright certificates and 7 patents for inventions. He founded a subsidiary research vector on the development of methods for increasing the reliability and energy efficiency of lifting transport machines, opening the way to science for the representatives of the third generation of the multilevel scientific school of Dobrovolsky, and also supervised seven candidate dissertations and one doctoral thesis.

Solomon Lev-Volfovich Mak (1910-1973) was involved in the study of lifting transport vehicles (Archive of ONPU, F. R-126/20/126.68, fol. 2). In his dissertation, Basic Provisions for the Design of Grapples (1939), Mak elaborated on the problem of the lack of scientific studies on scoops, which Dobrovolsky highlighted in his 1931 and 1934 monographs (Dobrovol'skij, 1931, p. 139). Studying grabs, Mak was one of the first to review their construction, pointed out the existing disadvantages, and the features of types of grabs for different materials (sand, ore). Mak published more than 50 works investigating machine parts and the strength of steel wire ropes. The directions of research developed by the scientist were continued by his students S. A. Gasparyan (1967), M. G. Stakyan (1968) and A. P. Davidov (1973).

A. A. Staroselsky (1940) investigated a topical problem for machine parts-the joints of parts. The scientist found that press connections are by nature frictional transmissions. He also invented and expanded information about the operation of these connections. Defined by Staroselsky, the research of press connections underwent substantial development in the writings of his students. Under Staroselsky's supervision, a number of dissertations devoted to the connection of details and shaft supports were completed, for example, by G. I. Kogan-Volman (1953), J. I. Belakovsky (1953), N. T. Rusnak (1955) and L. T. Balatsky (1964). 
O. S. Radchyk (1940) devoted his work to solve the problems of overheating of worm gearboxes and study their efficiency. The scientist found a solution to this problem by increasing the heat transfer to the environment, short-term mode of operation and the use of the ribbed surface of the gearbox, which increased its thermal power more than twice compared to the gearbox with a smooth surface (Radchik, 1940, p. 117).

Studies to measure the strength and weight of machine parts using strain gauges were started at the Department of Machine Parts under the direction of Dobrovolsky, and were expanded in the works of Radchyk's students. Under his supervision, theses were defended by V. V. Rvachev (1966), M. M. Starkman (1968), P. M. Timchenko (1973), and P. A. Gavrish (1974).

In 1940, Dobrovolsky, in cooperation with the Department of Machine Parts, carried out a study of cast iron bushes of crane supports for the Odessa heavy cranes plant, prompting him to consider the need to study the material of rolling bearings inserts for durability. A student of Dobrovolsky, I. E. Bloch (1947), elaborated on this problem in his dissertation. Bloch discovered the influence of the structure of the surface material of sleeves on the appearance and change of the coefficient of friction, which had not been previously reported (Bloch, 1947, p. 3), and proved the possibility of using ferrite cast iron for the manufacturing of bushings.

Under Dobrovolsky's supervision, Zaylin Weiner (1947) was involved in the study of rotation balancing automation. The researcher designed a device for balancing rotating parts, which allowed to accurately determine the magnitude and location of the imbalance and proposed the principle of independent oscillations, which did not complicate the design of the balancing machine, and allowed to simplify and completely automate the operations of determining the imbalance. The balancing machine developed by Weiner for the first time in the USSR, allowed efficient use of the balancing unit in conditions of mass production (Weiner, 1947, p. 60).

One of Dobrovolsky's most prominent students was Konstantin Ivanovich Zablonsky (1915-2006). In 1946, upon the personal address of Viktor Opanasovich Dobrovolsky, Zablonsky returned to Odessa and defended his dissertation on The Issue of Rigidity in the Calculation of High Power Gears (1948). Zablonsky was the first to draw attention to the lack of theoretically sound calculations for high power gears, and proved the conditionality of their results to determine rigidity. He proposed a new technique for calculating high power gears, which made it possible to determine the rigidity and permissible 
deformation according to a constructive transmission scheme (Zablonskij, 1947 , p. 216), resulting in the direction of research in the field of the rigidity of mechanical transmissions of load capacity in mechanical engineering, which the scientist developed in his doctoral thesis, defended in 1965.

In 1949, Zablonsky was head of the Department of Applied Mechanics of OPI, which continued to operate for the next 39 years. From 1969 to 1985 he worked as Rector of OPI, and received the title of Honored Worker of Science of the USSR (1975) (Archive of ONPU, F. R-126/60/10.197, fol. 79). The scientist paid considerable attention to the training of new scientific personnel and organized a subsidiary scientific school to study the rigidity of mechanical gears. Developing the research of calculation norms and designing of machine parts laid down by Dobrovolsky, Zablonsky passed Dobrovolsky's research paradigm on to his students, altogether 48 candidates and 5 doctors of science, which secured the sustainability of the legacy of scientific generations from the midtwentieth century to the present time.

Konstantin Ivanovich Zablonsky prepared a number of outstanding scientists of OPI, among whom was I. M. Bilokonev, doctor of technical sciences and professor at the Institute of Mechanical Engineering (1994), who founded the direction of research of automatic calculations in mechanical engineering and published about 120 scientific works. Bilokonev prepared his own graduate students—K. R. Ambartsumyants (1998), Yu. M. Svinarev (1999), vice-rector of Odessa National Polytechnic University, E. B. Kozarezov (2003). Among Zablonsky's students were also S. S. Hutyrya, doctor of technical sciences, professor and director of the Ukrainian-Spanish Institute and O. I. Sifonov (2009). Doctor of technical sciences I. I. Sidorenko (2008) defended the dissertation under Hutyrya's supervision. Zablonsky was the academic supervisor for the following scientists: B. M. Shchekin, doctor of technical sciences and Professor B. V. Motulko (1972).

Zablonsky's work consists of more than 430 scientific publications, including monographs Gear Rigidity, Calculation and Design of Gears, Gears, Integrated Gearboxes, Multithreaded Gearboxes and Planetary Gears.

Founded in 1932 by Dobrovolsky, the direction of research in bearings was developed further in the dissertation of M. Ya. Popereka (1949), who derived a method for detecting the influence of various factors on the durability of bearings and established the dependence of durability, on the nature of the work and the precision of manufacturing the elements of rolling (Popereka, 1949, p. 185). 
The scientific direction on the study of the drives of machine parts, formed by Dobrovolsky, was greatly expanded and furthered by his outstanding student Vasily Fedorovich Maltsev (1949). Maltsev substantiated the expediency of using impulse transmission in drives with a large range of regulation and gears with automatic control (Maltsev, 1949, p. 197). The researcher was one of the first Ukrainian scientists to develop basic design rules and outline the basic questions of the theory of impulse transmission.

Maltsev substantiated the concept of controlled drive machines and founded a subsidiary school to study the calculation and design of the mechanisms of idling and pulse variators. Under his supervision, 20 graduate students prepared and defended their dissertations, among them P. A. Kovalyev (1967), I. F. Soroka (1968), V. I. Krupskyy (1976), Ye. T. Burtsev, A. V. Nebesnova (1979), A. P. Ohanesyan (1979), P. A. Bondar (1981), M. I. Subotina (2004), Ye. A. Medvedyev, I. F. Knysh (Archive of ONAFT, F. 4/1-L/3344.155, fol. 83) and others.

Maltsev's total scientific achievement consists of about 300 publications and inventions (56 copyright patents) in the field of studies of gears and variators, and represents an important stage in the development of Ukrainian science.

K. S. Goncharenko (1950) investigated ways to increase the stability of materials of machine parts. During the Second World War, for the first time in the USSR, Goncharenko carried out porous chromium plating of internal combustion engine parts by electroplating. The scientist practically and theoretically substantiated the importance of electric chromium plating as a means of protecting parts from corrosion and developed a technological process of its application for all brands of cast iron (Goncharenko, 1950, p. 134).

The stability of materials of machine parts and their properties in the conditions of porous chrome plating was investigated by Israel Anatoliyovych Begahoyen (1950). Based on his research, he developed a method of jet chromium plating, which allowed the processing of dimensional details by low-power generators, to abandon the manufacture of baths to reduce the cost of materials and nonferrous metals. The method developed by Begahoyen made it possible to include chromium plating in the general technological process of manufacturing and restoring parts and the replacement of expensive Babbitt and bronze alloys (Begagoen, 1950, p. 210). 
Begahoyen worked at the Kryvyi Rih Mining Institute (modern Kryvyi Rih National University) and received the honorary title of Honored Worker of Science and Technology of the USSR. During his years at Kryvyi Rih National University, Begahoyen published about 150 scientific works on materials science and the longevity of machine parts (Stetskevich, 2012, p. 37). Israel Anatolyevich Begahoyen founded a branch of science dedicated to the problems of drilling machines and ways to increase the longevity of mining machines. Under his supervision, 15 candidate and 5 doctoral theses were defended, among others by V. I. Bykov, doctor of technical sciences, professor of Krivyi Rih National University (1965), A. G. Dyadura (1966), S. G. Rozhonov (1968), B. G. Bovdoui (1969), A. I. Bazhal (1969), A. I. Boyko (1971), A. P. Rudenko (1971) and L. A. Shablii (1973).

V. G. Shpytsya (1951) was the first in Ukrainian machine-building to consider the problem of the strength of bolts at impact load, taking into account the scheme of their work, the physical and mechanical properties of the material, structural forms and substantiating the importance of the design factor as a basis for determining stress in detail (Shpytsya, 1951, p. 146).

The research of I. V. Rodionov (1952) was devoted to the improvement of the methods of calculating gears. The scientist discovered a deviation from the law of mechanical similarity of geometrically identical teeth made of identical material, explained the reasons for the destruction of teeth from brittle materials using the static theory of brittle strength and supplemented the method of calculating teeth with the coefficient of influence of geometric dimensions of the tooth on its strength (Rodionov, 1952, p. 131).

Mykola Vasyl'ovych Oliynyk's work (1952) was one of the first studies in Ukrainian mechanical engineering devoted to the influence of turning and speed treatment on the fatigue strength of carbon steel. The researcher established a number of features of high-speed processing, substantiated the need to use plastic deformation and internal stresses in the design of the technological process of parts processing (Oliynyk, 1952, p. 13).

During his scientific career, Oliynyk published the following works: Endurance of Parts (1979), Acceleration of Fatigue Test (1985), and Carrying Capacity of Elements of Structures at Cyclic Load (1986). Oliynyk's total scientific achievements in the field of materials science and fatigue testing include about 500 publications, among them 32 monographs, and 50 copyright certificates (Medvedev, 2015, p. 7). 
Oliynyk paid great attention to individual work with students and organized a subsidiary scientific school in the field of resistance to fatigue of details and structural elements. In the course of his more than 50 years of pedagogical work, Oliynyk educated 35 candidates and 3 doctors of science. Under his supervision, the following dissertations were defended: A. V. Konoplyov, doctor of technical sciences, head of the Department of Mechanical Engineering of Odessa National Maritime University, corresponding member of the Transport Academy of Ukraine (1987), B. N. Lapin (1989), O. N. Pelyukhno, A. G. Kibakov (1994) and O. N. Shumilo (2008).

A. O. Sagarda (1953) developed a method for calculating the plastic deformation of surface layers of cylindrical joints while compressing them with a smooth and solid plane and experimentally proved the dependence of the surface hardness on the properties of metal and processing conditions (Sagarda, 1953, p. 137).

The work of Sagarda's student, L. M. Tomashevs'ka (1954), became a significant in-depth study into the bearings of sliding. The scientist carried out an experimental study of cast iron bearings with a ratio of their length to a diameter of $1: 0.25 / 0.3$, which significantly exceeded the norms adopted in Soviet science and proved the possibility of their application in the field of liquid friction (Tomashevs'ka, 1954, p. 209).

R. N. Lobunets (1955), in search of an alternative to metal ceramics, investigated the friction properties of a steel metallized layer, described options for improving the metallization process and the method of obtaining a metallized layer with increased hardness and wear resistance (Lobunets, 1955, p. 144).

Properties and wear resistance of three types of cast iron (modified, gray, with globular graphite) under the conditions of comprehensive static compression and cyclic contact loads were investigated by V. A. Alekseeva (1955), who thus refuted the opinion in the literature of the high resistance to wear in conditions of friction of sliding cast iron with globular graphite and emphasized the best performance of modified cast iron (Alekseeva, 1955, p. 112).

The technological processes of fabrication, operation and wear of various types of needle files at friction were considered in the work of B. I. Ivashin (1955). Ivashin developed a technology of manufacturing combs of needle files using the electrothermal method, increasing the efficiency and durability of needle files 1.5-2 times (Ivashin, 1955, p. 160). 
Mikhail Sergeevich Belyaev (1958) investigated the problem of specifying the norms and methods of calculating gears, to improve their efficiency and economy, substantiated the obsolescence of the existing method of calculation for bending and developed a method for determining the coefficient of deformation of a tooth at any point (Belyaev, 1958, p. 88). Belyaev's scientific work includes nearly 160 scientific publications, including the textbook Precision Mechanisms (1966) and monographs Designing Mechanisms and Devices (1971) and Reliability and Durability of Machines (1973).

Viktor Opanasovich Dobrovolsky's broad practical skills and his erudition allowed him to be an expert in various fields of scientific knowledge. Under his supervision, research was carried out by A. M. Perler (1939), who studied features of electrification of industrial enterprises; V. S. Diracu (1940), who studied current transformers in Ferrant; M. I. Gorbatov (1942), who studied high-speed friction disk bodies (Archive of ONPU, F. R-126//104.35, fol. 11); L. G. Kharitonov (1949), who investigated physical damage to bearing (Haritonov, 1949); I. A. Kosenko (1951), who studied mechanical wear and ways of rational finishing of the surface of machine parts; V. M. Pronin (1955), who studied increasing the durability of veneer joints; D. M. Petergeri (1958), who studied cyclic strength of steel in connection with the load regime and scale factor; B. V. Chelpanov (1958), who investigated the scientific direction of research of cheap cast iron bearings; K. I. Kostin (1956), who studied and calculated machine parts and properties of metals; and V. P. Dimkovsky (1963), who studied the traction characteristics of friction gears. Among Dobrovolsky's students who related their activities with OPI were S. V. Pinegin (professor at the Blagonravov Institute of Mechanical Engineering of the Russian Academy of Sciences) and Associate Professor N. A. Nikulin (Denisov \& Bondar', 2003, p. 121).

The scientific school of Viktor Opanasovich Dobrovolsky is an exceptional phenomenon, which emerged from the multifaceted personality of a scientist who had an undeniable scientific status, a certain pedagogical frenzy, the ability to sense and discover new directions in science and skills to solve practical problems. His comprehensive approach to scientific research, developed by Dobrovolsky on the basis of a harmonious combining of theoretical, experimental and practical work, was mastered by his students and provided them with the necessary methodological basis for scientific discoveries.

Today, the scientific school brings together three generations of scientists who continue to work in different universities of the country, keeping the weight 
of scientific traditions as a necessary basis for the successful development of Ukrainian science. Dobrovolsky's fundamental scientific works, worthily continued by the first generation of his students (M. V. Oliynyk, K. I. Zablonsky, V. F. Maltsev, L. B. Ehrlich and S. V. Mak) and multiplied by the following generations of his scientific school (V. F. Semenyuk, I. M. Bilokonev, S. S. Hutyrya and A. V. Konoplyov) continue to retain significant influence on the trends of modern science and find important practical applications that allow us to consider the scientific school of Viktor Opanasovich Dobrovolsky in the field of machine parts and materials science as widely recognized not only within OPI, but throughout Ukrainian machine-building industry.

\section{Viacheslav Bandus, PhD}

Odessa National Polytechnic University

\section{References}

Alekseeva, V. A. (1955), Iznos chugunov pri rabote ikh $v$ usloviiakh treniya kacheniias proskal'zyvaniem [Wear of cast irons during their operation in conditions of rolling friction with slippage], $\mathrm{PhD}$ thesis, Odessa Polytechnic Institute.

Archive of ONAFT, 'The personal files of Maltsev, Vasil Fedorovich' [in Russian], F. 4/1L/3344.155, Odessa National Academy of Food Technologies.

Archive of ONPU, 'The personal files of Gorbatov, N. I.' [in Russian], F. R-126//104.35, Odessa National Polytechnic University.

Archive of ONPU, 'The personal files of Ivashin, Boris Ivanovich' [in Russian], F. R-126/51/10.152, Odessa National Polytechnic University.

Archive of ONPU, 'The personal files of Mak, Solomon Lev-Wolfowitz' [in Russian], F. R-126/20/126.68, Odessa National Polytechnic University.

Archive of ONPU, 'The personal files of Oliynyk, Mikola Vasilovich' [in Russian], F. R-126/34/165.146, Odessa National Polytechnic University.

Archive of ONPU, 'The personal files of OPI employees' [in Russian], F. R-126/11.250, Odessa National Polytechnic University.

Archive of ONPU, 'The personal files of Zablons'kij, Kostyantin Ivanovich' [in Russian], F. R-126/60/10.197, Odessa National Polytechnic University.

Begagoen, I. A. (1950), Povysheniie dolgovechnosti mashinnykh detalei struinym khromirovaniem [Improving the durability of machine parts by jet chrome plating], $\mathrm{PhD}$ thesis, Odessa Polytechnic Institute.

Belyaev, M. S. (1958), Issledovaniie raspredeleniia nagruzki mezhdu odnovremenno zatseplyayushchimisia parami zub'ev priamozubykh koles [Investigation of the load 
distribution between simultaneously clinging pairs of teeth of spur gears], $\mathrm{PhD}$ thesis, Odessa Polytechnic Institute.

Bloch, I. E. (1947), Iznosoupornost' chugunnykh vtulok v kranovykh oporakh [Wear resistance of cast-iron bushings in crane supports], PhD thesis, Odessa Polytechnic Institute.

Chelpanov, B. V. (1958), Issledovaniie surmyanistogo chuguna kak podshipnikogo materiala [The study of antimony cast iron as a bearing material], $\mathrm{PhD}$ thesis, Odessa Polytechnic Institute.

Denisov, Y. S. \& Bondar', V. I. (2003), Istoriya Odesskogo politeknicheskogo v ocherkakh [History of Odessa Polytechnic in essays], 2nd ed., Odessa: ONPU \& Astroprint.

Department of Engineering Technology (n.d.), [Home page], Kryvyi Rih National University. Retrieved from http:/www.knu.edu.ua/en/fakultety/mehanikomashynobudivnyy-fakul-tet/struktura/kafedra-tehnolohii-mashynobuduvannya [accessed 25 Jan 2020]

Dimkovsky, V. P. (1963), Issledovaniie tyagovykh kharakteristik friktsionnykh peredach [Study of traction characteristics of friction gears], PhD thesis, Odessa Polytechnic Institute.

Diracu, V. S. (1940), Issledovaniie transformatorov toka po Ferranti i primenenie ikh $v$ nekotorykh skhemakh releinoi zashchity [Research of Ferranti current transformers and their application in some relay protection circuits], $\mathrm{PhD}$ thesis, Odessa Polytechnic Institute.

Dobrovol's'kij, V. O. (1931), Mnogocherpakovi sukhi zemlecherpalni priladi. Ekskavatori, trektsheri ta ditsheri: Konstruktsiia, teoriia, ekspluatatsiia, kharakteristika ta rozrakhunok [in Ukrainian; Multipurpose dry excavation devices. Excavators, trackers and ditchers: Design, theory, operation, characteristics and calculation], Kharkiv: State Inspectorate of Ukraine.

Gnatjuk, T. J.; Islamgulova, Z. H. \& Jakovleva, I. A. (2008), Viktor Opanasovich Dobrovol'skij. Bibliografichnyi pokazhchik [in Ukrainian; Viktor Opanasovich Dobrovolsky. Bibliographic index], Odessa: Nauka i teknika.

Goncharenko, K. S. (1950), Poristoe khromirovanie detalei mashin [Porous chrome plating of machine parts], PhD thesis, Odessa Polytechnic Institute.

Haritonov, L. G. (1949), Ustalostnye povrezhdeniya podshipnikov kacheniya [Fatigue damage to rolling bearings], PhD thesis, Odessa Polytechnic Institute.

Ivashin, B. I. (1955), Iznos stali pri trenii o grubosherohovatuyu poverhnost', obrabotannuiu elektroerozionnym i mekhanicheskim sposobami [Wear of steel during friction against a rough surface treated with electroerosive and mechanical methods], $\mathrm{PhD}$ thesis, Odessa Polytechnic Institute.

Kosenko, I. A. (1951), Vidoizmeneniie mikrogeometrii poverhnosti trushchihsya detalei v protsesse prirabotki $i$ kriterii prirabatyvaemosti [Modification of the microgeometry of the surface of rubbing parts during running-in and the criterion of run-in], $\mathrm{PhD}$ thesis, Odessa Polytechnic Institute. 
Kostin, K. I. (1956), Vliyaniie predvaritel'nogo vozdeistviia tsiklicheskikh napryazhenii na vynoslivost' konstrukcionnykh stalei [The influence of the preliminary influence of cyclic stresses on the endurance of structural steels], $\mathrm{PhD}$ thesis, Odessa Polytechnic Institute.

Lobunets, R. N. (1955), Issledovaniie friktsionnykh svoistv stal'nogo metallizatsionnogo sloya [Investigation of the frictional properties of a steel metallization layer], $\mathrm{PhD}$ thesis, Odessa Polytechnic Institute.

Maltsev, V. F. (1949), Issledovaniie impul'sivnoi besstupenchatoi peredachi [Impulse transmission research], PhD thesis, Odessa Polytechnic Institute.

Medvedev, S. A. (2015), 'Sekrety tvorchestva uchenogo-pedagoga' [Secrets of the work of the scientist-teacher], Visnik Odeskogo natsionalnogo morskogo universitetu - Bulletin of the Odessa National Maritime University, vol. 46, no. 4, pp. 5-8.

Odessa National Polytechnic University (n.d.), [Home page], Department of Mechanical Engineering and Machine Parts. Retrieved from https://opu.ua/kaf-mdm [accessed 25 Jan 2020]

Oliynyk, M. V. (1952), Vliyanie vysokoskorostnoi tokarnoi obrabotki na predel ustalosti stali [The effect of high-speed turning on the fatigue limit of steel], $\mathrm{PhD}$ thesis, Odessa Polytechnic Institute.

Perler, A. M. (1939), Normativy $i$ metody ratsional'nogo osveshcheniia predpriatii konservnoi promyshlennosti [Standards and methods for rational coverage of canning industry enterprises], PhD thesis, Odessa Polytechnic Institute.

Petergeri, D. M. (1958), Issledovaniie tsiklicheskoi prochnosti stali v sviazi s rezhimom nagruzheniia $i$ masshtabnym faktorom [Investigation of the cyclic strength of steel in connection with the loading regime and the scale factor], $\mathrm{PhD}$ thesis, Odessa Polytechnic Institute.

Popereka, M. Ya. (1949), Vliyaniie raznorazmernosti tel kacheniya na dolgovechnost' $i$ kharakter raboty radial'nykh podshipnikov [The effect of the different sizes of rolling elements on the durability and nature of the operation of radial bearings], $\mathrm{PhD}$ thesis, Odessa Polytechnic Institute.

Pronin, V. M. (1955), Vliyaniie shponochnykh kanavok na vynoslivost' pri izgibe [Effect of keyways on bending endurance], $\mathrm{PhD}$ thesis, Odessa Polytechnic Institute.

Radchik, A. S. (1940), Issledovaniie chervyachnykh reduktorov s obduvom [Study of worm gearboxes with blowing], PhD thesis, Odessa Polytechnic Institute.

Rodionov, I. V. (1952), Vliyaniie razmerov zuba na ego prochnost' [The influence of tooth size (gear train) on its strength], PhD thesis, Odessa Polytechnic Institute.

Sagarda, A. A. (1953), Deformaciia poverkhnostnykh sloyov detalei silindricheskikh soedinenii s garantirovannym natyagom [Deformation of the surface layers of parts of cylindrical joints with a guaranteed interference fit], $\mathrm{PhD}$ thesis, Odessa Polytechnic Institute.

Shpytsya, V. G. (1951), Voprosy udarnoi prochnosti boltov [Questions impact strength bolts], PhD thesis, Odessa Polytechnic Institute. 
Staroselsky, A. A. (1940), Pressovye posadki [Press landing], PhD thesis, Odessa Polytechnic Institute.

Stetskevich, V. V. (2012), Profesori KGR-KTU. Krivij Rig [in Ukrainian; Professors KGRI-KTU. Kryvyi Rih], Kryvyi Rih: KNU Publishing House.

Til, I. M. (1954), Issledovaniie novogo protsessa otlivki metallicheskikh dugovykh (byugel'nykh) zubnykkh protezov vysokoi tochnosti [Investigation of a new process of casting metal arc (clasp) dentures of high accuracy], $\mathrm{PhD}$ thesis, Odessa Polytechnic Institute.

Tomashevs'ka, L. M. (1954), Issledovaniie vozmozhnosti ukorocheniya chugunnogo podshipnika skol'zheniia pri rabote $v$ usloviyakh zhidkostnogo treniya $i$ opredelenie ego gruzopod"emnosti [Investigation of the possibility of shortening a cast-iron sliding bearing when working in liquid friction conditions and determining its load capacity], PhD thesis, Odessa Polytechnic Institute.

Weiner, Z. E. (1947), Novyi printsip raboty mashin dlia dinamicheskogo uravnoveshivaniia vrashchaiushchihsia detalei [A new principle of operation of machines for dynamically balancing rotating part], $\mathrm{PhD}$ thesis, Odessa Polytechnic Institute.

Zablonskij, K. I. (1947), Voprosy zhestkosti pri raschete zubchatykh peredach bol'shoi moshchnosti [Stiffness issues in the calculation of high power gears], $\mathrm{PhD}$ thesis, Odessa Polytechnic Institute. 